\title{
Polarographic Behavior of Arsenite at a Rotating Platinum Electrode and Amperometric Determination of Arsenite with N-Bromosuccinimide
}

\author{
by \\ Toyoshi Nagai, Toshio Matsuda and Yoshihiro Sugrmoto \\ (Department of Chemistry, Faculty of Science and Engneering, Ritsumeikan University, Kyoto)
}

(Received Aug. 25, 1972)

\begin{abstract}
The polarographic behavior of arsenite at a rotating platinum electrode and the amperometric determination of arsenite with N-bromosuccinimide were investigated.

Arsenite gave a peak-shaped oxidation wave, having the half-peak potential at $+0.50 \mathrm{~V}$ vs. SCE, in an electrolyte solution cotaining $0.1 M \mathrm{KNO}_{3}$ and Britton-Robinson buffer of $\mathrm{pH} 5.0$. Arsenite did not show any remarkable reduction wave except a cathodic peak at about $-0.5 \mathrm{~V} v s$. SCE. The diffusion current of the oxidation wave, measured at $+0.60 \mathrm{~V}$, was found to be proportional to the concentration of arsenite from $10^{-3}$ to $2 \times 10^{-5} \mathrm{~N}$ within the deviations of $\pm 2.0 \%$. Its temperature coefficient was determined to be 1.9 per cent $\operatorname{deg}^{-1}$ at $25 \pm 0.5^{\circ} \mathrm{C}$.

Arsenite in the low concentration over the range from $10^{-3}$ to $8 \times 10^{-5} \mathrm{~N}$ could be determined within an error of $\pm 2.0 \%$ by the short-circuit amperometric titration with $\mathrm{N}$-bromosuccinimide by use of a rotating platinum electrode.
\end{abstract}

\section{Introduction}

In the previous report ${ }^{1)}$, the polarographic behavior of $\mathrm{N}$-bromosuccinimide (NBS) at a rotating platinum electrode (RPE) has been investigated in an electrolyte solution containing $0.1 \mathrm{MNO}_{3}$ and Britton-Robinson (B.R.) buffer at $\mathrm{pH}$ 5.0. Barakat and co-worker ${ }^{2)}$ have reported on the volumetric determination of arsenite with NBS in a solution containing sodium hydrogen carbonate using iodine-starch as a visual indicator. Berka and et al. ${ }^{3)}$ have reviewed that NBS and arsenite react quantitatively over the wide $\mathrm{pH}$ range of the solution, and NBS can be standardized by arsenite by use of the potentiometric titration. Kolthoff et al. ${ }^{4)}$ have reported on the polarographic behavior of arsenite at a RPE that arsenite gives a small anodic wave in the vicinity of $+0.2 \mathrm{~V}$ vs. SCE in a solution containing sodium hydrogen carbonate.

From lack of the detailed polarographic data of arsenite at a RPE we investigated first in this report on the polarographic behavior of arsenite at a RPE in an electrolyte solution containing $0.1 \mathrm{M} \mathrm{KNO}_{3}$ and B.R. buffer at pH 5.0, and then on the amperometric determination of arsenite with NBS in the same medium by use of a RPE.

\section{Experimental}

\section{Apparatus and reagent}

A Shimadzu synchronous rotator, Type RE-3, was used with a vertical platinum wire microelectrode $(5.0 \mathrm{~mm}$ long, $0.5 \mathrm{~mm}$ in diameter) at the rate of $600 \mathrm{rpm}$. A 
Yanagimoto polarograph, Type PA-101, was used to record a polarogram. The details on the experimental conditions are described in the previous report ${ }^{1)}$.

The standard solution of sodium arsenite: Arsenous acid anhydride of analytical reagent grade, $\mathrm{As}_{2} \mathrm{O}_{3}$, was used to prepare a $0.1000 \mathrm{~N}(=0.0500 \mathrm{M})$ arsenite solution by the conventional method. Dilute sulfuric acid was used to neutralize the solution.

The standard solution of NBS: The solution was prepared freshly before use in the daily experiments as described in the previous report ${ }^{1}$.

\section{Results and Discussion}

Polarogram of arsenite at $\mathrm{pH}$ 5.0.

As a daily test before each run for a polarogram of arsenite, the polarograms of potassium ferricyanide in an electrolyte solution containing $0.1 M \mathrm{KNO}_{3}$ and B.R. buffer at $\mathrm{pH} 5.0$ were recorded by use of the RPE which had been pretreated in a 0.1 $\mathrm{NHClO}_{4}$ solution, as described in the previous report ${ }^{5)}$. The values obtained for the diffusion current and the half-wave potential of potassium ferricyanide were checked to recognize the conditions for preoxidation and rotation of the electrode, etc.

Polarograms of arsenite were recorded after preparation of an electrolyte solution as follows: An adequate amount of sodium arsenite solution was added to the base solution, i.e., $0.1 \mathrm{M} \mathrm{KNO}_{3}$ and B.R. buffer of $\mathrm{pH} 5.0$, in a $50 \mathrm{ml}$ measuring flask, and diluted to the mark with distilled water. An aliquot of the solution was further deoxygenated in an electrolyte cell for a while before the polarogram was recorded. Polarograms were recorded by forward scan or backward scan. By forward scan, the electrode potential was shifted from positive to negative potentials. By backward scan, the situation was reversed.

The polarograms of $8 \times 10^{-4} N$ arsenite are shown in Fig. 1. Curve 1 (forward) was recorded from $+1.0 \mathrm{~V}$ after preoxidation at $+1.3 \mathrm{~V}$ for several minutes. Curves 2 and 3 (backward) were recorded from $-0.5 \mathrm{~V}$ and $-0.3 \mathrm{~V}$, respectively, after preoxidation as in curve 1.

By the forward scan from $+1.0 \mathrm{~V}$, a small oxidation wave at about +0.5 $\mathrm{V}$, a cathodic dissolution pattern of platinum oxide layer at about $+0.1 \mathrm{~V}$ and a small cathodic peak at about $-0.5 \mathrm{~V}$ were observed as shown in curve 1 . The hydrogen reduction wave started at the more negative potential by about $350 \mathrm{mV}$ than the starting potential of hydrogen wave in the base solution. The polarogram is shown in curve 4. A value of an anodic current of the oxidation wave at about $+0.5 \mathrm{~V}$ was not reproducible and became smaller, when the elapsed time for the preo-

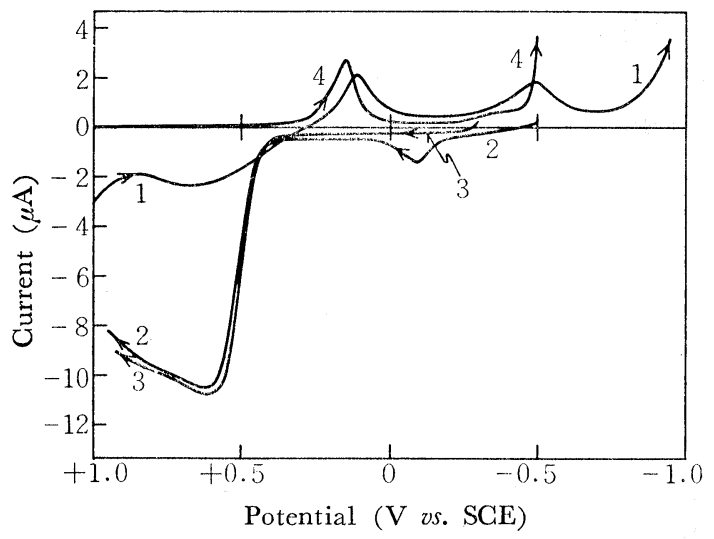

Fig. 1. Polarogram of $8 \times 10^{-4} N$ arsenite in $0.1 M$ $\mathrm{KNO}_{3}$ with B.R. buffer at $\mathrm{pH} 5.08$.

1 : Forward from $+1.0 \mathrm{~V}$ after preoxidation at $+1.3 \mathrm{~V}$.

2 : Backward from $-0.5 \mathrm{~V}$ after preoxidation at $+1.3 \mathrm{~V}$.

3 : Backward from $-0.3 \mathrm{~V}$ after preoxidation at $+1.3 \mathrm{~V}$.

4 : Same as in curve 1 (residual current). 
xidation at $+1.3 \mathrm{~V}$ became longer. These results might be due to the reduction of platinum oxide layer by arsenite, as reported by Kolthoff and Tanaka ${ }^{6)}$.

By the backward scan from $-0.5 \mathrm{~V}$, a small anodic peak at about $-0.1 \mathrm{~V}$ and a well-defined peak-shaped oxidation wave at about $+0.5 \mathrm{~V}$ were observed as shown in curve 2. By the backward scan from $-0.3 \mathrm{~V}$, only the latter wave was observed at about $+0.5 \mathrm{~V}$ as shown in curve 3 .

On the other hand, when a polarogram was plotted manually by the forward scan from $+1.0 \mathrm{~V}$, it was coincident with curve 4 , except that the hydrogen wave appeared at the more negative potential by about $350 \mathrm{mV}$ than the starting potential of hydrogen wave in curve 4 . When a polarogram was plotted manually by the backward scan from $-0.5 \mathrm{~V}$, the small anodic peak at about $-0.1 \mathrm{~V}$ disappeared and only the peak-shaped oxidation wave at about $+0.5 \mathrm{~V}$ was observed. The latter wave was coincident with the waves at about $+0.5 \mathrm{~V}$ in curves 2 and 3 recorded by the backward scan with respect to the values of anodic peak current and half-peak potential.

It was supposed that the cathodic peak at about $-0.5 \mathrm{~V}$ in curve 1 would be due to the reduction of arsenite to elemental arsenic or arsine and the anodic peak at about $-0.1 \mathrm{~V}$ in curve 2 would be due to the oxidation of such reduction products deposited or adsorbed on the electrode surface. Such reduction products on the electrode surface affected the reduction of hydrogen ion on the platinum electrode and the hydrogen wave started late by about $350 \mathrm{mV}$, as shown in curve 1 . The anodic peak at about $-0.1 \mathrm{~V}$, however, did not affect the peak-shaped oxidation wave at about $+0.5 \mathrm{~V}$, as shown in curve 2.

The following experiments were forcused on the polarographic behavior of the peak-shaped oxidation wave of arsenite at about $+0.5 \mathrm{~V}$, because it has been reported ${ }^{7)}$ that the plarographic behavior of arsenite in the cathodic region is complicated even at a dropping mercury electrode.

Effect of the recording conditions on the backward polarogram

In Fig. 2 are shown four backward polarograms of $8 \times 10^{-4} \mathrm{~N}$ arsenite and of the base solution at $\mathrm{pH}$ 5.0. Curve 1 was recorded from $-0.3 \mathrm{~V}$ just after preoxidation at $+1.3 \mathrm{~V}$ for several minutes. Gurves 2 and 3 were recorded from $-0.3 \mathrm{~V}$ after preoxidation as in curve 1 , followed by polarization at $-0.3 \mathrm{~V}$ for 3 minutes (curve 2) and 5 minutes (curve 3), respectively. Gurve 4 was recorded from $-0.3 \mathrm{~V}$ in the base solution after preoxidation as in curve 1.

As shown in the three backward polarograms, their half-peak potentials shifted to the more positive potentials

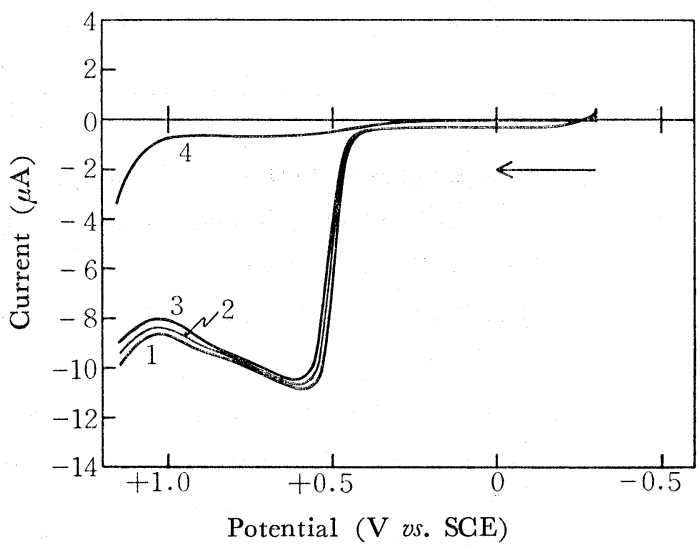

Fig. 2. Effect of the electrode preconditioning on the backward polarogram of $8 \times 10^{-4} \mathrm{~N}$ arsenite in $0.1 M \mathrm{KNO}_{3}$ with B.R. buffer at $\mathrm{pH}$ 5.08.

1 : From $-0.3 \mathrm{~V}$ after preoxidation at +1.3 V.

2 : From $-0.3 \mathrm{~V}$ after preoxidation at +1.3 $\mathrm{V}$. followed by polarization at $-0.3 \mathrm{~V}$ for 3 minutes.

3 : From $-0.3 \mathrm{~V}$ after preoxidation at +1.3 $\mathrm{V}$ followed by polarization at $-0.3 \mathrm{~V}$ for 5 minutes.

4 : Same as in curve 1 (residual current). 
as the polarization time at $-0.3 \mathrm{~V}$ before recording became longer. The reason for this shift of the half-peak potential might be due to the deactivation effect of an active electrode surface, as noted in the previous report ${ }^{5}$.

From the data obtained with the recording condition in curve 1 the half-peak potential of the oxidation wave was found to be $+0.50 \pm 0.01 \mathrm{~V}$ and the peak current measured at $+0.60 \mathrm{~V}$ was reproducible within the deviations of $\pm 1.5 \%$ during about 50 minutes, necessary for repeating 5 runs of polarograms.

Relation between the peak current and the concentration of arsenite.

Table I shows that the value of peak current (average of duplicate values) is proportinal to the concentration over the range from $10^{-3}$ to $2 \times 10^{-5} \mathrm{~N}$ arsenite at $\mathrm{pH}$ 5.0 within the deviations of $\pm 2.0 \%$. The values of peak current were measured at $+0.60 \mathrm{~V}$ and corrected for the residual current.

Table I. Relation between the peak current and the concentration of arsenite in $0.1 M$ $\mathrm{KNO}_{3}$ with B.R. buffer at $\mathrm{pH} 5.09$

\begin{tabular}{c|c|c|c}
\hline $\begin{array}{c}\text { Concn. of arsinite } \\
\mathrm{G}(\mathrm{N})\end{array}$ & $\begin{array}{c}\text { Peak current } \\
-\mathrm{i}_{\mathrm{p}}(\mu \mathrm{A})\end{array}$ & $\begin{array}{c}-\mathrm{i}_{\mathrm{p}} / \mathrm{G} \\
(\mu \mathrm{A} / \mathrm{meq} / 1)\end{array}$ & $\begin{array}{c}\text { Dev. } \\
(\%)\end{array}$ \\
\hline $1.000 \times 10^{-3}$ & 12.79 & 12.79 & -1.2 \\
$8.000 \times 10^{-4}$ & 10.31 & 12.89 & -0.5 \\
$4.000 \times 10^{-4}$ & 5.17 & 12.93 & -0.2 \\
$2.000 \times 10^{-4}$ & 2.58 & 12.90 & -0.4 \\
$1.000 \times 10^{-4}$ & 1.314 & 13.14 & +1.5 \\
$8.000 \times 10^{-5}$ & 1.035 & 12.94 & -0.1 \\
$4.000 \times 10^{-5}$ & 0.511 & 12.78 & -1.3 \\
$2.000 \times 10^{-5}$ & 0.264 & 13.20 & +1.9 \\
\hline
\end{tabular}

The temperature coefficient of the peak current of arsenite over the temperature range from 11 to $31^{\circ} \mathrm{C}$ was determined to be 1.9 per cent $\operatorname{deg}^{-1}$ at $25 \pm 0.5^{\circ} \mathrm{C}$ in the test solution of $8 \times 10^{-4} \mathrm{~N}$ arsenite at $\mathrm{pH}$ 5.0.

From these results, the peak current of arsenite at $\mathrm{pH} 5.0$ is considered to be controlled by diffusion.

Evaluation of the number of electron involved in the electrode reaction.

From the equation for diffusion current at a RPE, the following relation is derived between the ratio of the limiting current per unit normal concentration of arsenite to that of ferricyanide ion and the ratio of the diffusion coefficient of arsenite to that of ferricyanide ion, under the same experimental condition;

$$
\left(i_{d} / C\right)_{\mathrm{As}(\mathrm{III})} /\left(i_{\mathrm{d}} / C\right)_{\mathrm{Fe}(\mathrm{CN}) 6}{ }^{3-}=\left(D_{\mathrm{As}(\mathrm{III})} / D_{\mathrm{Fe}(\mathrm{CN}) 6}{ }^{3-}\right)^{2 / 3}
$$

where $C$ means concentration in normality.

Test solutions of sodium arsenite and potassium ferricyanide were prepared in the same concentrations of $8 \times 10^{-4} \mathrm{~N}$ at $\mathrm{pH}$ 5.0. The ratio of the diffusion current per unit normal concentration of arsenite to that of ferricyanide ion at a RPE was determined to be 1.2 at $25 \pm 0.5^{\circ} \mathrm{C}$.

It has been reported by Kolthoff and co-worker ${ }^{8)}$ that arsenite ion shows an oxidation wave in a $0.5 \mathrm{M}$ potassium hydroxide solution at a dropping mercury electrode. 
With reference to this report, the diffusion coefficient for arsenite ion was determined in this laboratory to be $1.03 \times 10^{-5} \mathrm{~cm}^{2} / \mathrm{sec}$ at $25^{\circ} \mathrm{C}$ from the polarographic data using a dropping mercury electrode in a test solution of $10^{-3} \mathrm{~N}$ sodium arsenite containing $0.1 M \mathrm{KNO}_{3}, 0.1 M \mathrm{KOH}$ and $0.01 \%$ polyacrylamide. The diffusion coefficient for ferricyanide ion in the same base solution has been determined to be $0.87 \times 10^{-5}$ $\mathrm{cm}^{2} / \mathrm{sec}$ at $25^{\circ} \mathrm{C}$ in the previous report ${ }^{5}$. The value of $2 / 3$ power of ratio of the diffusion coefficient of arsenite ion to that of ferricyanide ion was calculated to be 1.1, using both values noted above.

Both values of the ratio, i.e. 1.2 and 1.1 , were fairly coincidental with each other. It is considered, therefore, that the number of electron involved in an electrooxidation of arsenite is 2 and that arsenite is oxidized to arsenate, as known in the redox titration with arsenite as follows ${ }^{9)}$ :

$$
\mathrm{H}_{3} \mathrm{AsO}_{3}+\mathrm{H}_{2} \mathrm{O} \longrightarrow \mathrm{HAsO}_{4}{ }^{2-}+4 \mathrm{H}^{+}+2 \mathrm{e}^{-}
$$

The degree of dependence of the half-peak potential on $\mathrm{pH}$ of the solution, as shown in Fig. 3, was $-58 \mathrm{mV}$ per $\mathrm{pH}$ over the $\mathrm{pH}$ range from 2 to 7 . In these experiments, each backward polarogram of $8 \times 10^{-4} \mathrm{~N}$ arsenite solutions at $\mathrm{pH}$ value from 2 to 7 was recorded

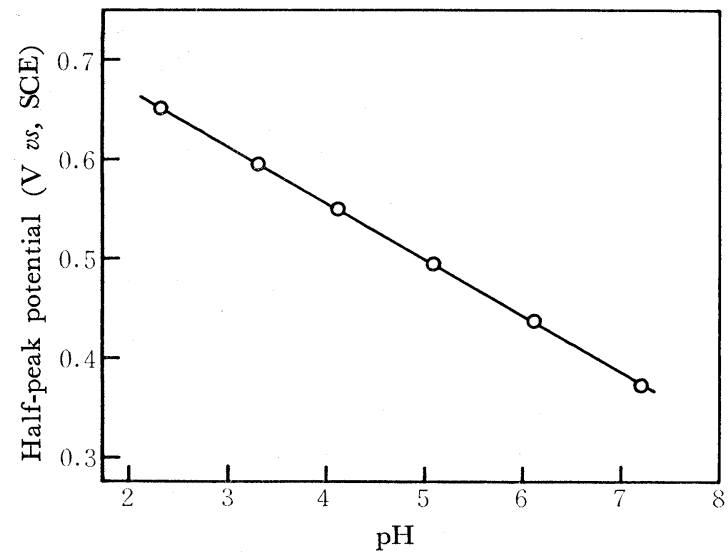

Fig. 3. Dependence of half-peak potential of oxidation wave of $8 \times 10^{-4} \mathrm{~N}$ arsenite on $\mathrm{pH}$ of the solution.

from the more positive potential by about $100 \mathrm{mV}$ than the starting potential of the cathodic peak of arsenite, just after preoxidation at the potential from +1.3 to +1.5 V. The values of the peak current of arsenite over this $\mathrm{pH}$ range were coincidental within the deviations of $\pm 1.5 \%$.

\section{Amperometric determination of arsenite with NBS.}

Amperometric titration of arsenite with NBS could be accomplished by use of a RPE in a B.R. buffer at pH 5.0 at the potential of $0 \mathrm{~V} v s$. SCE, based on the data from the polarographic investigation of NBS and arsenite at a RPE.

Each arsenite test solution, containing a B.R. buffer at pH 5.0 and $0.1 \mathrm{M} \mathrm{KNO}_{3}$, was prepared in a $100 \mathrm{ml}$ measurig flask over the concentration range from $10^{-3}$ to $2 \times 10^{-5} \mathrm{~N}$ sodium arsenite. $50 \mathrm{ml}$ of this solution was pipetted out into a glass cylinder cell (diameter $45 \mathrm{~mm}$, height $75 \mathrm{~mm}$ ) and was deoxygenated with $N_{2}$ gas for about 20 minutes. A RPE as an indicator electrode and a SCE through a $30 \% \mathrm{KNO}_{3}$ agar bridge as a reference electrode were set in the titration cell. The standard solution of NBS at an appropriate concentration was added from a brown microburette. After each addition of the NBS solution, the titrated solution was mixed by passing $\mathrm{N}_{2}$ gas for about 2 minutes. The value of the diffusion current of NBS was corrected for the dilution effect.

Plots of diffusion current $v s$. titrant volume showed a reverse L-shaped curve, as shown in Fig. 4. Titration results are presented in Table II. Titration results of $10^{-3} \mathrm{~N}$ arsenite in the presence of arsenate or chloride are presented in Table III.

From these results, arsenite in the low concentration range from $10^{-3}$ to $8 \times 10^{-5}$ 
$N$ could be determined with NBS by the short-circuit amperometric titration using a RPE within an error of $\pm 2.0 \%$.

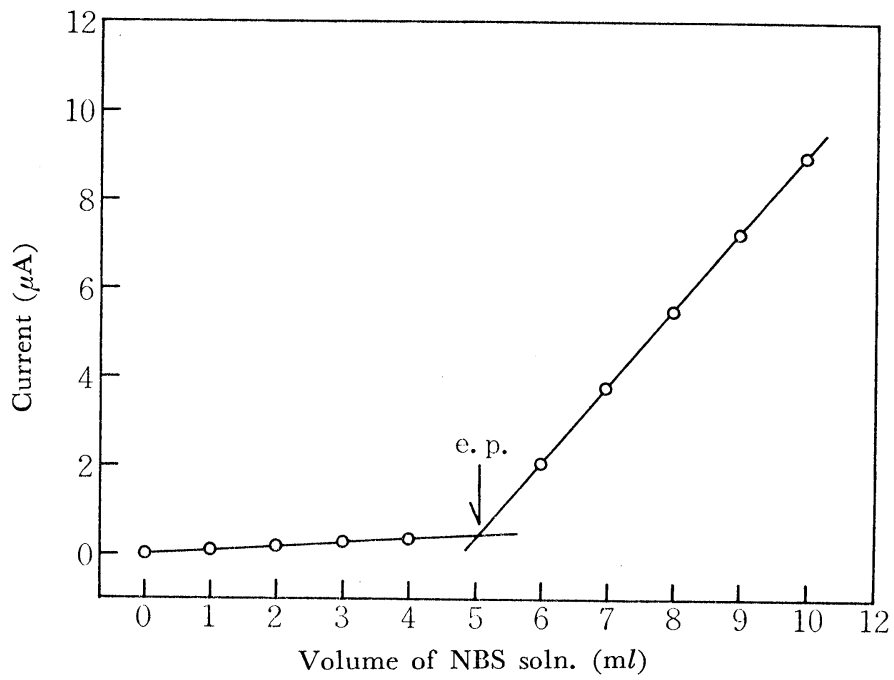

Fig. 4. Amperometric titration curve of $1.000 \times 10^{-3} \mathrm{~N}$ arsenite with $0.983 \times 10^{-2} \mathrm{~N}$ NBS.

Table II. Results of amperometric titration of arsenite with NBS.

\begin{tabular}{|c|c|c|c|c|c|}
\hline \multirow{2}{*}{$\begin{array}{l}\text { Concn. of } \\
\text { arsenite } \\
(N)\end{array}$} & \multirow{2}{*}{$\begin{array}{c}\text { Concn. of } \\
\text { NBS } \\
(N)\end{array}$} & \multicolumn{3}{|c|}{ NBS solution } & \multirow{2}{*}{$\begin{array}{c}\text { Average } \\
\text { error } \\
(\%)\end{array}$} \\
\hline & & $\begin{array}{l}\text { Calcd. } \\
\quad(\mathrm{m} l)\end{array}$ & $\begin{array}{l}\text { Found } \\
\quad(\mathrm{m} l)\end{array}$ & $\begin{array}{l}\text { Average } \\
\quad(\mathrm{m} l)\end{array}$ & \\
\hline $1.000 \times 10^{-3}$ & $0.983 \times 10^{-2}$ & 5.09 & $\begin{array}{l}5.09 \\
5.03 \\
5.04\end{array}$ & 5.05 & -0.8 \\
\hline $8.000 \times 10^{-4}$ & $0.989 \times 10^{-2}$ & 4.04 & $\begin{array}{l}4.05 \\
4.04\end{array}$ & 4.05 & +0.2 \\
\hline $5.000 \times 10^{-4}$ & $0.983 \times 10^{-2}$ & 2.54 & $\begin{array}{l}2.54 \\
2.54 \\
2.50\end{array}$ & 2.53 & -0.4 \\
\hline $2.000 \times 10^{-4}$ & $0.983 \times 10^{-2}$ & 1.02 & $\begin{array}{l}1.02 \\
1.00 \\
1.01 \\
5.20\end{array}$ & 1.01 & -1.0 \\
\hline $1.000 \times 10^{-4}$ & $0.989 \times 10^{-3}$ & 5.06 & $\begin{array}{l}5.03 \\
5.06\end{array}$ & 5.10 & +0.8 \\
\hline $8.000 \times 10^{-5}$ & $0.989 \times 10^{-3}$ & 4.04 & $\begin{array}{l}4.03 \\
4.04 \\
2.65\end{array}$ & 4.04 & 0.0 \\
\hline $5.000 \times 10^{-5}$ & $0.989 \times 10^{-3}$ & 2.53 & $\begin{array}{l}2.50 \\
2.61\end{array}$ & 2.59 & +2.4 \\
\hline $2.000 \times 10^{-5}$ & $0.983 \times 10^{-3}$ & 1.02 & $\begin{array}{l}0.98 \\
0.99 \\
1.05\end{array}$ & 1.01 & -1.0 \\
\hline
\end{tabular}


Table III. Effect of arsenate and chloride on the titration results of arsenite*.

\begin{tabular}{|c|c|c|c|c|}
\hline \multirow{2}{*}{$\begin{array}{c}\text { Goncn. of } \mathrm{Na}_{2} \mathrm{HAsO}_{4} \\
\text { or } \mathrm{KCl} \text { added }\end{array}$} & \multicolumn{3}{|c|}{ NBS solution } & \multirow{2}{*}{$\begin{array}{l}\text { Average } \\
\text { error } \\
(\%)\end{array}$} \\
\hline & $\begin{array}{l}\text { Calcd. } \\
(\mathrm{m} l)\end{array}$ & $\begin{array}{c}\text { Found } \\
(\mathrm{m} l)\end{array}$ & $\begin{array}{l}\text { Average } \\
(\mathrm{m} l)\end{array}$ & \\
\hline no addition & 5.11 & $\begin{array}{l}5.07 \\
5.07\end{array}$ & 5.07 & -0.8 \\
\hline $5.0 \times 10^{-2} M \mathrm{Na}_{2} \mathrm{HAsO}_{4}$ & 5.11 & $\begin{array}{l}5.08 \\
5.05\end{array}$ & 5.07 & -0.8 \\
\hline $5.0 \times 10^{-3} M \mathrm{Na}_{2} \mathrm{HAsO}_{4}$ & 5.11 & $\begin{array}{l}5.08 \\
5.07\end{array}$ & 5.08 & -0.6 \\
\hline $5.0 \times 10^{-2} M \mathrm{KCl}$ & 5.11 & $\begin{array}{l}5.04 \\
5.17\end{array}$ & 5.11 & 0.0 \\
\hline $5.0 \times 10^{-3} M \mathrm{KGl}$ & 5.11 & $\begin{array}{l}5.14 \\
5.14\end{array}$ & 5.14 & +0.6 \\
\hline
\end{tabular}

* Test soln. : $50 \mathrm{ml}$ of $1.000 \times 10^{-3} \mathrm{~N}$ arsenite in $0.1 M \mathrm{KNO}_{3}$ with B.R. buffer at $\mathrm{pH} 5.0$.

Titrant : $0.978 \times 10^{-2} N$ NBS.

\section{References}

1) T. Nagai and T. Matsuda, Rev. Polarog. (Kyoto), 17, 133 (1971).

2) M.Z. Barakat and A. Abdalla, Analyst, 85, 288 (1960).

3) A. Berka, J. Valterin and J. Zýka, "Newer Redox Titrants", p. 52, Pergamon Press (1965).

4) I.M. Kolthoff, W. Stricks and L. Morren, Analyst, 78, 405 (1953).

5) T. Nagai and T. Matsuda, Rev. Polarog. (Kyoto), 16, 16 (1969).

6) I.M. Kolthoff and N. Tanaka, Anal. Chem., 26, 632 (1954).

7) J.J. Lingane, Ind. Eng. Chem., Anal. Ed., 15, 583 (1943).

8) I.M. Kolthoff and R.L. Probst, Anal. Chem., 21, 753 (1949).

9) H.A. Laitinen, "Chemical Analysis", p. 402, McGraw-Hill Book Co. (1960).

回転白金電極に打ける亜七酸塩のポーラログラフ的挙動および Nーブロムスクシンイミドを用いる亜ヒ酸塩の電流滴定法による定量

\section{永井外代士，松田十四夫，杉本 宣弘 (立命館大学理工学部化学教窒)}

回転白金電極における亜ヒ酸塩のポーラログラフ的 挙動を検討するとともに，N-ブロムスクシンイミド (NBS) を用いる電流滴定法を亜七酸塩の定量に適用 した.

亜七酸塩は， $0.1 \mathrm{M} \mathrm{KNO}_{3}$ および Britton-Robinson 緩衝液を含む $\mathrm{pH} 5.0$ の電解液中で, +0.50 V vs. $\mathrm{SCE}$ に半ピーク電位を持つ 1 段のピーク状の酸化波 を示す。還元波については， $-0.5 \mathrm{~V}$ 付近に小さなピ 一ク状の還元電流が現われるのみで，はっきりとした 波はみられなかった。

酸化波のピーク電流は， $10^{-3} \sim 2 \times 10^{-5} \mathrm{~N}$ 範囲で $\pm 2.0 \%$ 以内の偏差で濃度に比例する拡散電流であり, $25^{\circ} \mathrm{C}$ における温度係数は $1.9 \% /{ }^{\circ} \mathrm{C}$ であった。

一方，乙れらの結果をもとにして，NBS を用いる 亜七酸塩の電流滴定を行なった。 $0.1 \mathrm{M} \mathrm{KNO} \mathrm{KN}_{3}$ おび Britton-Robinson 緩衝液を含む pH5.0 の西と酸塩 試料液を被滴定液とし，NBS 標準溶液を滴定液とし て, $0 \mathrm{~V}$ vs SGE 亿電位を設定して電流滴定を行なっ た. その結果, $10^{-3} \sim 8 \times 10^{-5} \mathrm{~N}$ の範囲の低濃度の亜 七酸塩を $\pm 2.0 \%$ 以内の䛊差で, 短絡電流滴定法によ り定量できた。 